\title{
DESIGN AND ANALYSIS OF DISC BRAKE ROTOR USING DIFFERENT PROFILES
}

\author{
A. S. Abrar Ahmed, V. Ayush Kumar, S. Gokul, P.Vijay \\ UG students \\ Department of Mechanical Engineering, \\ Panimalar Institute of Technology, \\ Poonamallee, Chennai-600 123
}

\begin{abstract}
The main objective of this project is to propose a new automotive brake disc rotor design for BAJAJ PULSAR 150 which will reduce the total deformation and increase the maximum heat dissipation. Here various shapes of ventilated holes in brake disc rotor is designed using AUTODESK INVENTOR 2019. The inner and outer boundaries are preserved so that the changes are made only in the intermediate patterns between the boundaries, thus the models have same structural boundary limits. The static structural analysis and steady state thermal analysis of brake disc rotor is done using ANSYS 19, which is a dedicated finite element package used for determining the temperature distribution, variation of the stresses and deformation across the disc brake profile. The assembly analysis method, is carried out for static structural analysis to increase the accuracy of result. The best of the designed brake disc rotor is to be suggested based on the magnitude of von misses stresses, deformation, temperature, total heat flux, and weight.
\end{abstract}

Keywords - brake disc rotor, intermediate patterns, static structural analysis, steady state thermal analysis.

\section{INTRODUCTION}

The disc brake is a device which specially use for slowing or stopping the rotation of a wheel. Repetitive braking of the vehicle going generates heat during each braking movements. The finite element method is a powerful method which are used for the numerical solutions of a wide range of engineering problems.

The disc brake is a wheel brake which slows rotation of the wheel by the friction which caused by pushing brake pads towards a brake disc with a set of calipers. Brakes convert motion to heat, and if the brakes get

\author{
C. Parthasarathy \\ Assistant Professor, \\ Department of Mechanical Engineering, \\ Panimalar Institute of Technology, \\ Poonamallee, Chennai-600 123
}

too hot, they become less effective, this phenomenon known as brake fade, Disc brake consisting structural steel disc bolted to the wheel hub and a stationary housing which is known as caliper.

The caliper is connected to some stationery part of the vehicle like the stub axle as is cast in two parts each part consist of a piston. In between each piston and the disc there is a frictional pad hold in position by detainments pins, spring plates. The passages are so connected to another one for bleeding. Each cylinder contains rubber-sealing ring which placed between the cylinder and piston.

The aim is to compare the structural and thermal properties of rotor disc during braking, of standard motorcycle "BAJAJ PULSAR 150" with a nonstandard rotor disc and to find out the difference in structural and thermal properties.

\section{METHODOLOGY}

\section{A. Design of existing model}

The existing model of brake disc rotor is designed based on analytical measurements and standard values available from the standard website. The standard brake disc rotor that we consider here is from BAJAJ PULSAR 150. The brake disc rotor of BAJAJ PULSAR 150 is designed using AUTODESK INVENTOR 2019.

\section{B. Evaluation of existing model}

The designed existing model of disc rotor is analyzed structurally and thermally to study its properties using ANSYS 19.

Material used

The knowledge of materials and their properties is of great significance for a design engineer. The machine elements should be made of such a material which has properties suitable for the conditions of operation, in addition to this a design engineer must 


\section{International Journal of Engineering Applied Sciences and Technology, 2020 \\ Vol. 4, Issue 9, ISSN No. 2455-2143, Pages 286-293 \\ Published Online January 2020 in IJEAST (http://www.ijeast.com)}

be familiar with the effects which the manufacturing processes and heat treatment have in the properties of the materials. Hence, from standard reference grey cast iron and aluminium alloys are used as brake disc materials, based on reference from vehicle reviewers and dealers site grey cast iron is chosen as the standard brake disc rotor material.

Properties of grey cast iron

1. Chemical Properties of grey cast iron According to the different grades, the grey cast iron has different chemical components, however, normally, all gray iron grades have the following chemical component range:

Carbon (C) 2.8 - 3.9\%, Silicon (Si) 1.1 - 2.6\%, Manganese (Mn) $0.5-1.2 \%, \mathrm{P} \leq 0.3 \%, \mathrm{~S} \leq 0.15 \%$. However, you cannot inspect the quality by chemical components. The iron foundries have right to adjust them as long as they can meet the mechanical properties.

2. Mechanical Properties of grey cast iron According to the different grades, grey cast iron has different mechanical properties. Their tensile strength is between $72500 \mathrm{psi}$ to 188500 psi. The yield strength is between 21700 psi to 72500 psi. Grey iron castings almost have no elongation. The impact toughness is less than 11 $\mathrm{J} / \mathrm{cm} 2$, so if your parts need to stand impact, then ductile iron will be the better choice. The hardness of gray iron is between 145 to 280 HBS. If customers have special requirements to the hardness, you should tell the casting suppliers, otherwise, hardness cannot be an inspection standard.

Mechanical Properties of grey cast iron:

\begin{tabular}{lll}
\hline Mechanical Property & Value & Unit \\
\hline Young's Modulus & 118 & $\mathrm{GPa}$ \\
Tensile Strength & 310 & $\mathrm{MPa}$ \\
Yield Strength & 575 & $\mathrm{MPa}$ \\
Poisson's ratio & 0.30 & - \\
\hline
\end{tabular}

Tab. (1)

Structural analysis

In structural analysis the deformation in steady state boundary conditions is analyzed. The brake torque, clamping force, brake pad area is given as an input boundary condition. The resulting output like total deformation, directional deformation, von-misses stress, max principal stress, etc., have been analyzed. Thermal analysis
In steady state thermal analysis, the properties like temperature distribution, amount of heat transferred is analyzed from the boundary condition like, surface temperature during braking, convection occurring in brake disc, etc.

\section{Alternative models}

To improve the efficiency of brake disc rotor the alternative design models are proposed preserving the inner and outer boundary. Thus the changes are made on the intermediate faces between the inner and outer boundary and in some cases on exterior surface edges too.

Design of alternate models

The alternate models are made using holes, cuts, slots, etc., and making the patterns on different sets on different radii with increased and decreased hole radii the alternative models are made. The alternate models are designed using AUTODESK INVENTOR 2019.

Analysis of alternate models

The alternate models are individually analyzed for the calculated structural boundary conditions and the same as for thermal boundary condition. The alternate models are analysed both structurally and thermally using ANSYS 19.

\section{Result comparison}

The results are tabulated based on the models and their structural output results followed by the thermal output results.

The Structural analysis output results to be tabulated are total deformation, von misses stress, etc, The Thermal analysis output results to be tabulated are temperature, total heat flux, etc,

The best model is selected from the results which is better from all background values.

\section{CALCULATIONS}

\section{A. Initial conditions and assumptions}

To make the calculation perfect the initial condition are taken from dealer site and the relevant assumptions are made as follows

- The total weight of the vehicle is assumed to be $300 \mathrm{Kg}$.

- The vehicle is assumed to travel at a maximum speed of $100 \mathrm{kmph}$, i.e., $\mathrm{v}=27.77 \mathrm{~m} / \mathrm{s}$

- The axial weight distribution is taken as 0.5

- The coefficient of friction is assumed to be 0.5

- The effective radius is taken as, $\mathrm{R}$ eff $=0.12 \mathrm{~m}$ 
- $\quad$ The Kinetic energy to absorbed is taken as 0.9

- The standard hydraulic pressure is taken as 1 Mpa

- The coefficient of friction is same for brake pad and rotor, i.e., $\mu \mathrm{I}=\mu \mathrm{O}$.

- The ambient temperature is taken as $23^{\circ} \mathrm{C}$

- The vehicle is said to stop using 1 brake caliper, i.e., the stopping distance is taken as $50 \mathrm{~m}$

- The brake pad's total coverage angle is measured to be $42.5^{\circ}$

- $\quad$ The vehicle has varying leverage and actuation based on driving condition so, a FOS of 2.5 is taken into consideration for single stop surface temperature rise.

- The tangential clamping force between the brake pad and rotor on inside is equal to outside, i.e., FTRI = FTRO, FRI = FRO.

\section{B. Calculations}

Structural calculations

$$
\begin{aligned}
& \text { Brk pad cont area, } \mathrm{A}=\left(\pi(\mathrm{r} 1)^{\wedge} 2-\pi(\mathrm{r} 2)^{\wedge} 2\right) * \theta / 360 \\
& \quad=\left(\pi(120)^{\wedge} 2-\pi(95)^{\wedge} 2\right) * 42.5 / 360 \\
& \quad=1993.49 \approx 2000 \mathrm{~mm}^{\wedge} 2=0.002 \mathrm{~m}^{\wedge} 2
\end{aligned}
$$

Norm force on inn side, $\mathrm{FRI}=((\mathrm{P} \max / 2) \mathrm{x} \mathrm{A})$

$$
\begin{aligned}
& =\left(\left(1 * 10^{\wedge} 6\right) / 2 * 0.002\right) \\
& =((1000000) / 2 * 0.002) \\
& =(500000 * 0.002) \\
& =1000 \mathrm{~N}
\end{aligned}
$$

Tang react force on inn side, FTRI $=\mu \mathrm{I} x$ FRI

$$
\begin{aligned}
& =(0.5 * 1000) \\
& =500 \mathrm{~N}
\end{aligned}
$$

Tang react force on outside, $\mathrm{FTRO}=\mu \mathrm{O} \times \mathrm{FRO}$

$$
\begin{aligned}
& =(0.5 * 1000) \\
& =500 \mathrm{~N}
\end{aligned}
$$

Tang clamping force, FT $=$ FTRI + FTRO

$$
\begin{aligned}
& =500+500 \\
& =1000 \mathrm{~N}
\end{aligned}
$$

Brake torque, $\mathrm{TB}=\mathrm{FT} *$ Reff

$$
\begin{gathered}
=1000 * 0.12 \\
=120 \mathrm{~N}-\mathrm{m}
\end{gathered}
$$

Thermal calculations

Braking time, $\mathrm{d}=(\mathrm{u}+\mathrm{v}) / 2 * \mathrm{t}$

$$
\begin{aligned}
50 & =(0+27.77) / 2 * \mathrm{t} \\
13.885 \mathrm{t} & =50 \\
\mathrm{t} & =3.6 \mathrm{~s}
\end{aligned}
$$

kinetic energy, K.E $=\gamma \mathrm{k} *\left(\mathrm{~m}(\mathrm{u}-\mathrm{v})^{\wedge} 2\right) / 2$

$$
\begin{aligned}
& =(0.5)(0.9) *\left((300)(0-27.77)^{\wedge} 2\right) / 2 \\
& =(0.5)(0.9) *(115675.5) \\
& =52053.98 \mathrm{~J}
\end{aligned}
$$

Braking power, $\mathrm{Pb}=\mathrm{K} . \mathrm{E} / \mathrm{t}$

$$
=52053.98 / 3.6
$$

$$
=14459.44 \mathrm{~W}
$$

Max. contact area, $\mathrm{A} 1=\pi(\mathrm{r} 1)^{\wedge} 2$

$$
\begin{aligned}
& =\pi *(120)^{\wedge} 2 \\
& =45238.93 \mathrm{~mm}^{\wedge} 2
\end{aligned}
$$

Min. contact area, $\mathrm{A} 2=\pi(\mathrm{r} 2)^{\wedge} 2$

$$
\begin{aligned}
& =\pi *(95)^{\wedge} 2 \\
& =28352.87 \mathrm{~mm}^{\wedge} 2
\end{aligned}
$$

Net disc contact area, $\mathrm{A}=\mathrm{A} 1-\mathrm{A} 2$

$$
\begin{aligned}
& =45238.93-28352.87 \\
& =\quad 16886.06 \quad \mathrm{~mm}^{\wedge} 2 \\
& =0.01688 \mathrm{~m}^{\wedge} 2
\end{aligned}
$$

Heat flux, $\mathrm{q}=\mathrm{Pb} / \mathrm{A}$

$$
\begin{aligned}
& =14459.44 / 0.01688 \\
& =856601.89 \mathrm{~W} / \mathrm{m}^{\wedge} 2
\end{aligned}
$$

Max temperature, $\quad \operatorname{Tmax}=\frac{0.527 * \mathrm{q} * \sqrt{\mathrm{t}}}{\sqrt{(\rho * \mathrm{c} * \mathrm{k})}}+\mathrm{Tamb}$

$$
\begin{aligned}
& =\frac{0.527 * 856601.89 * \sqrt{3.6}}{\sqrt{(6600 * 460 * 50)}+296} \\
& =\frac{0.527 * 856601.89 * 1.897}{\sqrt{151800000}}+296 \\
& =\frac{856361.18}{12320.71}+296 \\
& =69.505+296=365.505 \mathrm{~K} \\
& =92.505^{\circ} \mathrm{c} \approx 93^{\circ} \mathrm{c}
\end{aligned}
$$

Considering, $\mathrm{FOS}=2.5$

$$
\begin{aligned}
& =2.5 * 93=232.5 \approx 250{ }^{\circ} \mathrm{C} \\
\mathrm{T} \max & =250^{\circ} \mathrm{C}
\end{aligned}
$$

\section{DESIGN OF DISC BRAKE ROTORS}

\section{A. Standard brake disc}

The standard brake disc is designed containing $8 \mathrm{~mm}$ holes on circular patterns along the radii.

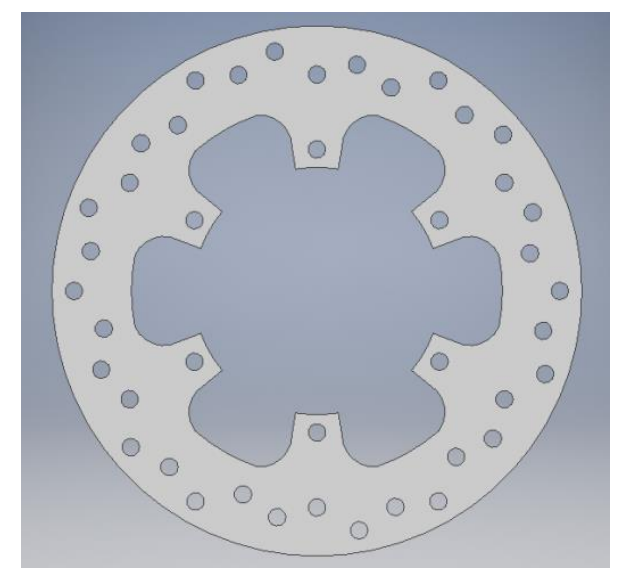

Fig (a) standard brake disc 1

\section{B. Alternate brake disc}




\section{International Journal of Engineering Applied Sciences and Technology, 2020 \\ Vol. 4, Issue 9, ISSN No. 2455-2143, Pages 286-293 \\ Published Online January 2020 in IJEAST (http://www.ijeast.com)}

The alternate brake disc is designed containing $8 \mathrm{~mm}$ holes angularly on circular patterns.

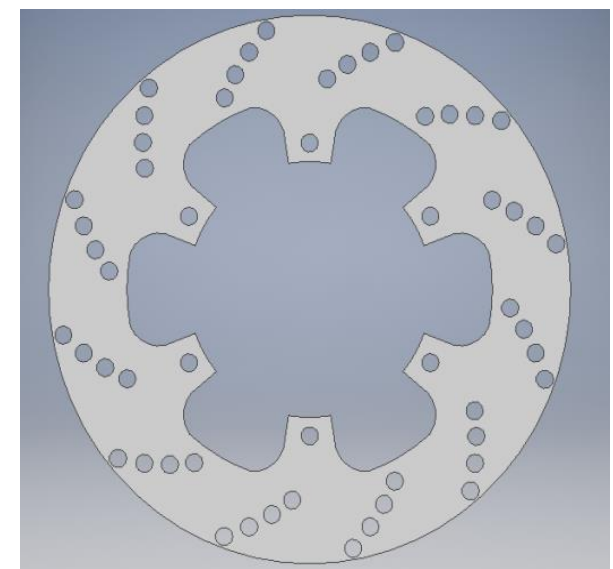

Fig (b) alternate brake disc 2

\section{Alternate brake disc 3}

The alternate brake disc is designed containing $8 \mathrm{~mm}$ holes angularly on circular patterns, with circular notch on the circumference of disc.

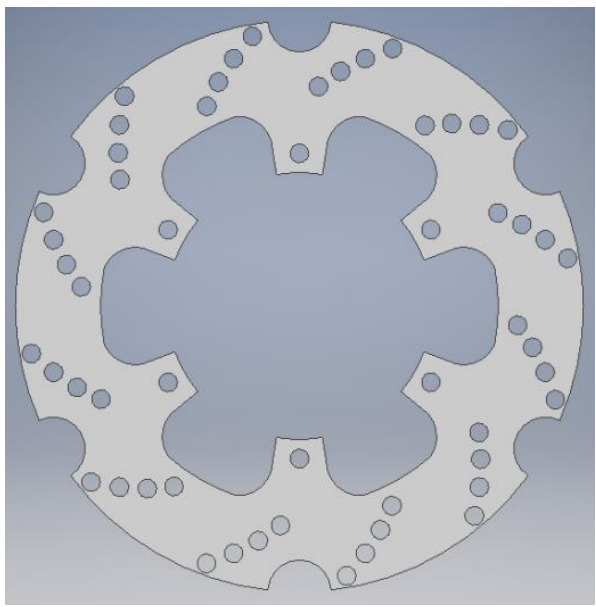

Fig (c) alternate brake disc 3

\section{Alternate brake disc 4}

The alternate brake disc is designed containing $8 \mathrm{~mm}$ holes on circular patterns along the radii.

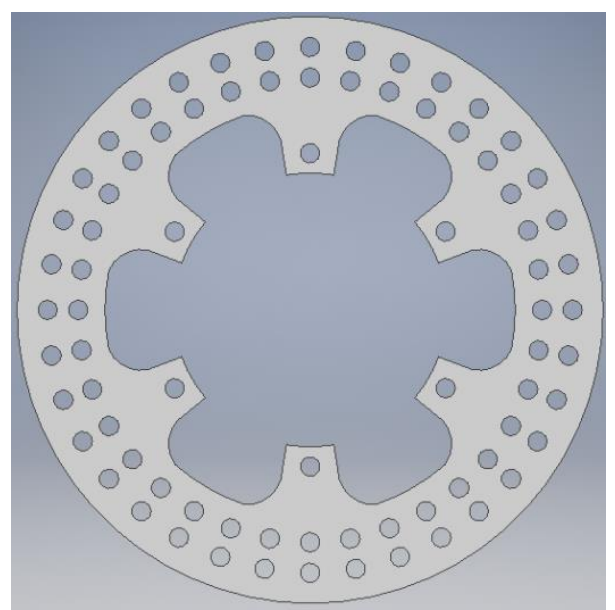

Fig (d) alternate brake disc 4

\section{E. Alternate brake disc 5}

The alternate brake disc is designed containing $8 \mathrm{~mm}$ holes angularly on circular patterns, with $\mathrm{V}$ notch on the circumference of disc.

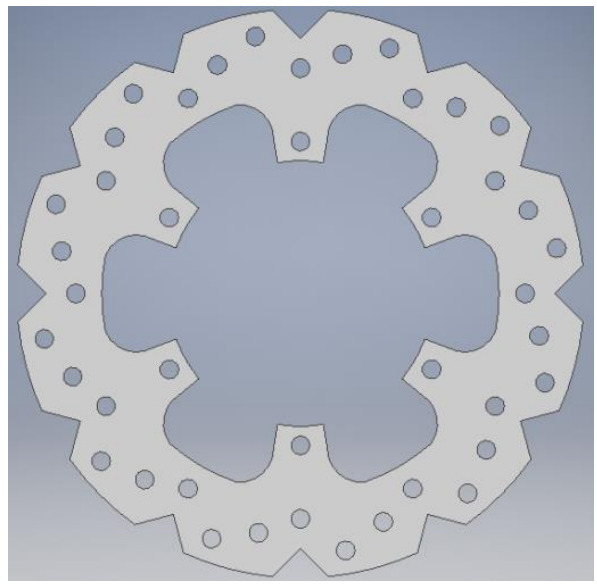

Fig (e) alternate brake disc 5

\section{F. Alternate brake disc 6}

The alternate brake disc is designed containing slots angularly on circular patterns, with $\mathrm{V}$ notch on the circumference of disc.

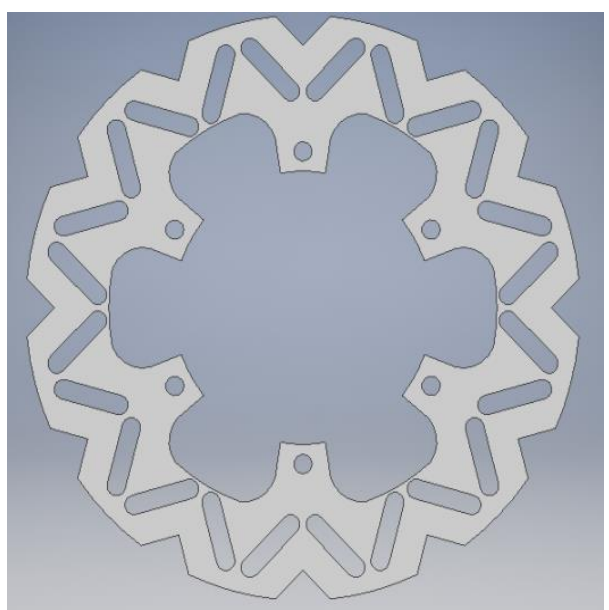




\section{ANALYSIS OF DISC BRAKE ROTORS}

Structural analysis

Boundary conditions

- 6 inner bolt holes - FIXED

- brake torque $-120 \mathrm{~N}-\mathrm{m}$

- tangential force - $1000 \mathrm{~N}$ (applied using brake pads)

- material - grey cast iron

- brake pad displacement - 0,0,free

- mesh - preferred size

\section{Brake pads}

The brake pads of area $0.002 \mathrm{~m}^{\wedge} 2$ is designed on both sides of the disc using ANSYS 19 DESIGN MODELER to apply the tangential force.

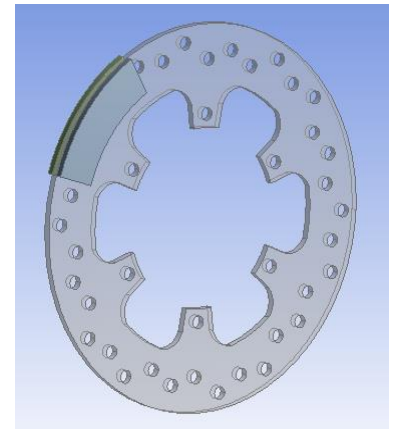

Fig. (1) brake pad

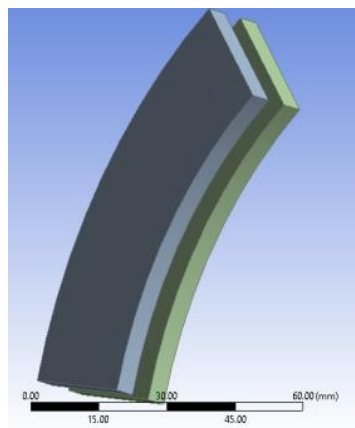

Fig. (2) brake pad

\section{Results}

\section{A. Standard disc 1}

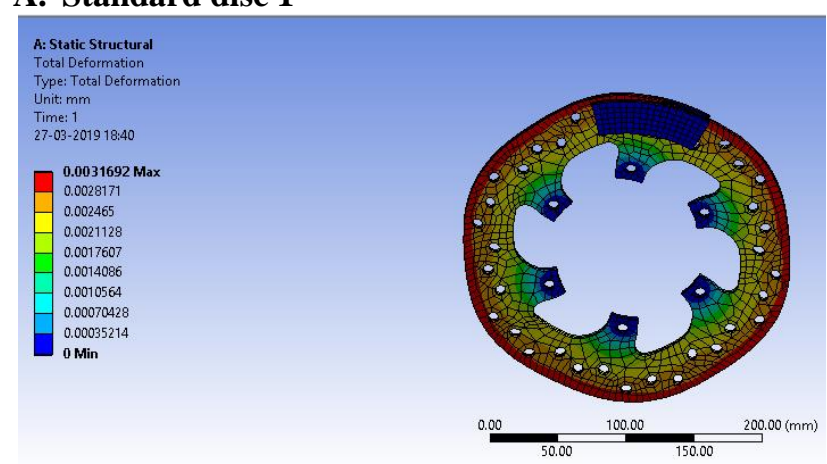

Fig. (a). Total deformation of standard disc 1

\section{B. Alternate disc 2}

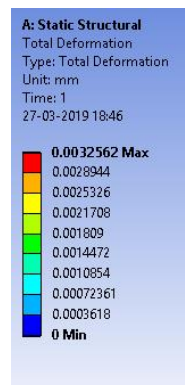

Fig. (b). Total deformation of alternate disc 2

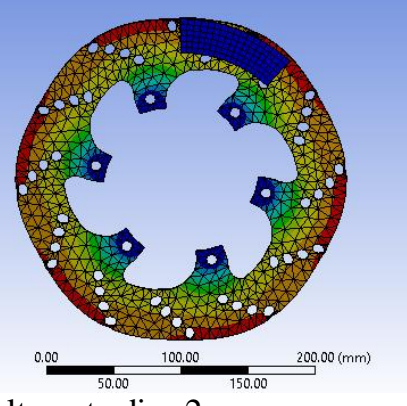

\section{Alternate disc 3}

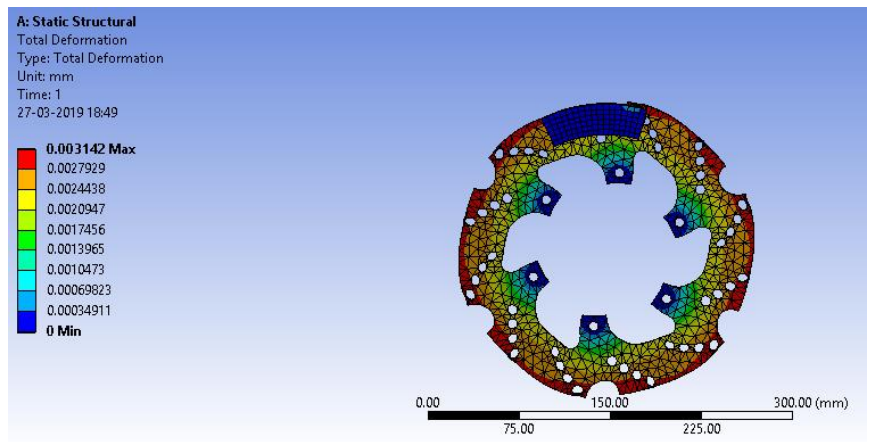

Fig. (c). Total deformation of alternate disc 3

D. Alternate disc 4

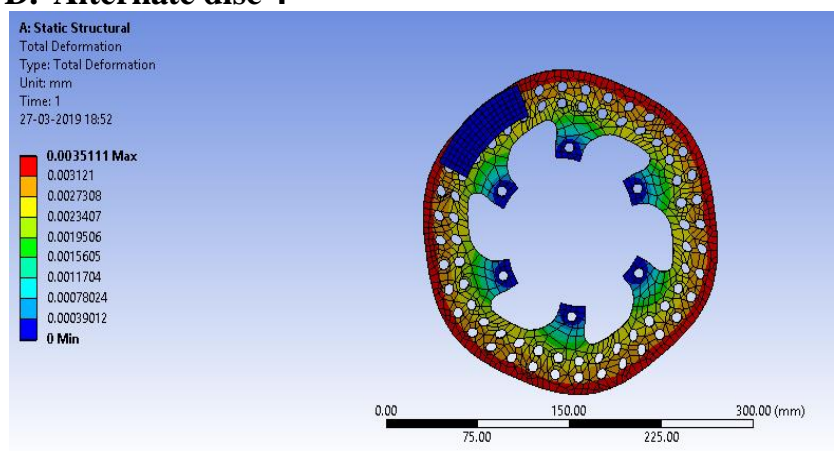

Fig. (d). Total deformation of alternate disc 4

\section{E. Alternate disc 5}

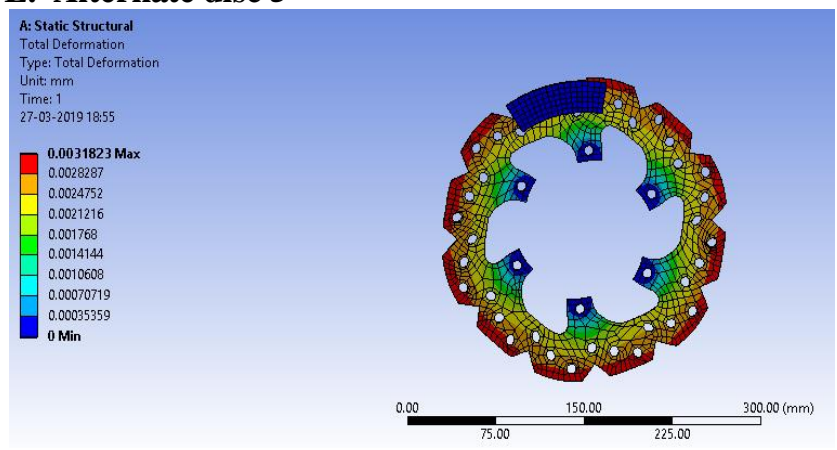

Fig. (e). Total deformation of alternate disc 5 


\section{F. Alternate disc 6}

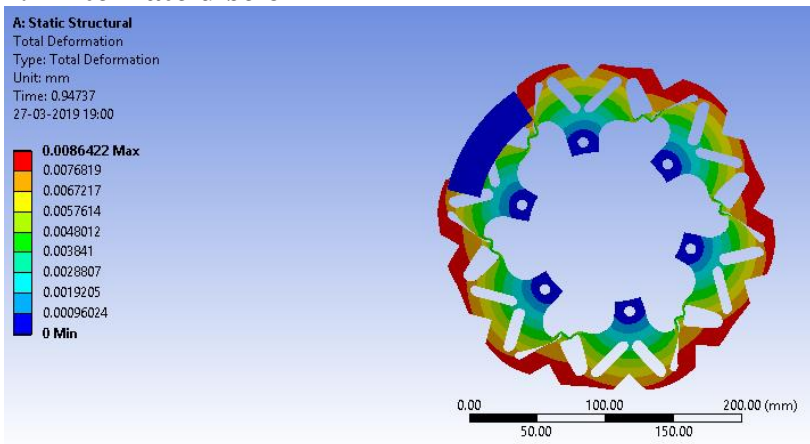

Fig. (f). Total deformation of alternate disc 6

Thermal analysis

Boundary conditions

- maximum permissible temperature $-250^{\circ} \mathrm{C}$

- ambient temperature $-23^{\circ} \mathrm{c}$

- convection - through non contact area in disc

\section{Results}

\section{A. Standard disc 1}

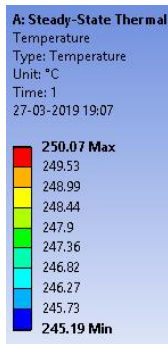

Fig. (a). Temperature of standard disc 1

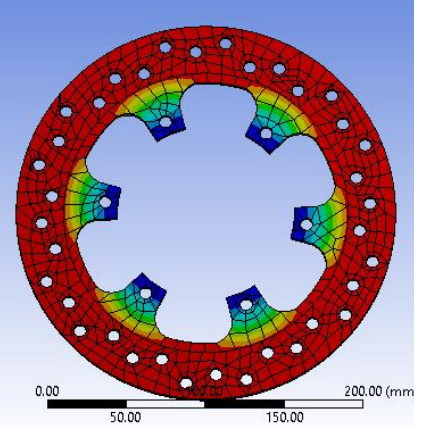

B. Alternate disc 2

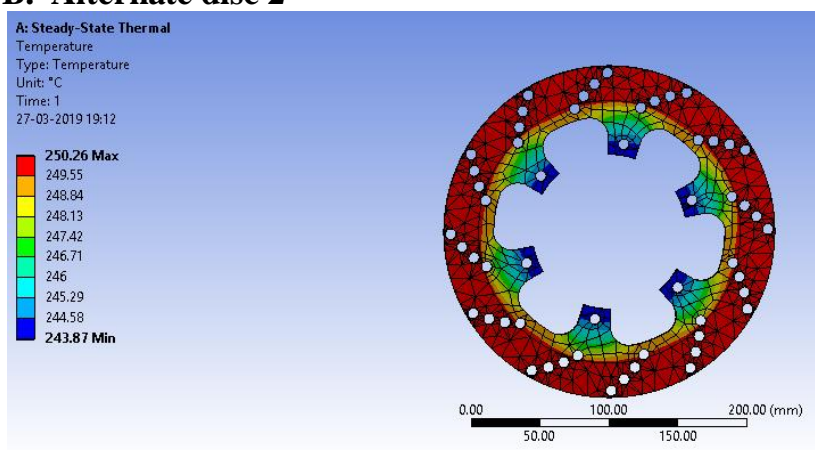

Fig. (b). Temperature of alternate disc 2

C. Alternate disc 3

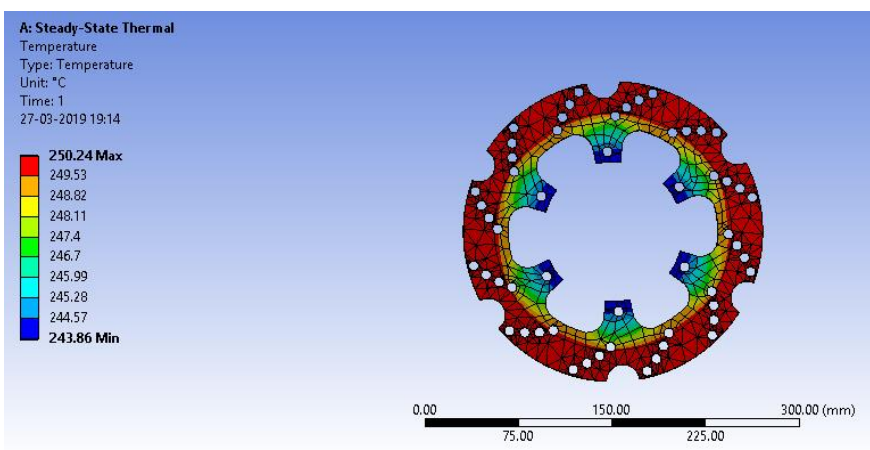

Fig. (c). Temperature of alternate disc 3

D. Alternate disc 4

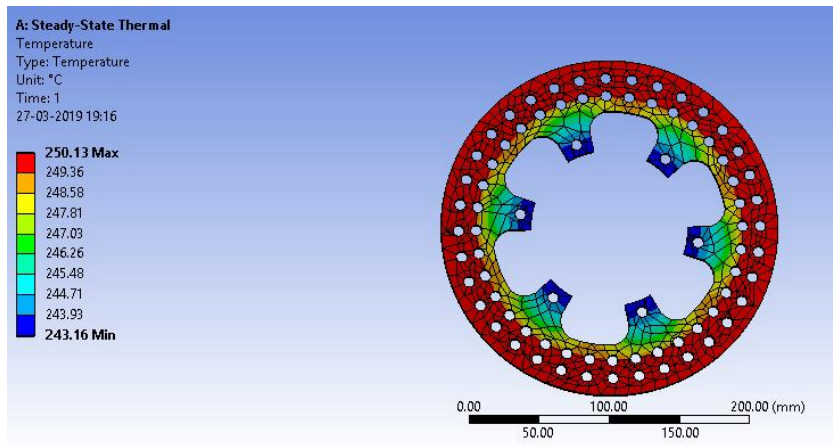

Fig. (d). Temperature of alternate disc 4

\section{E. Alternate disc 5}

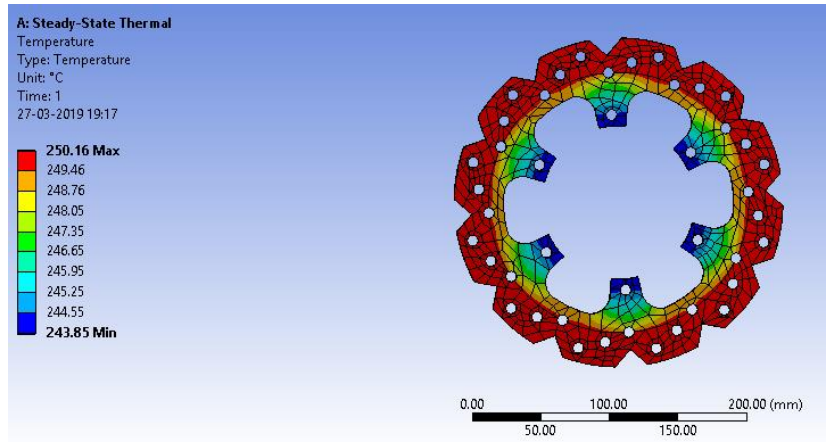

Fig. (e). Temperature of alternate disc 5

F. Alternate disc 6

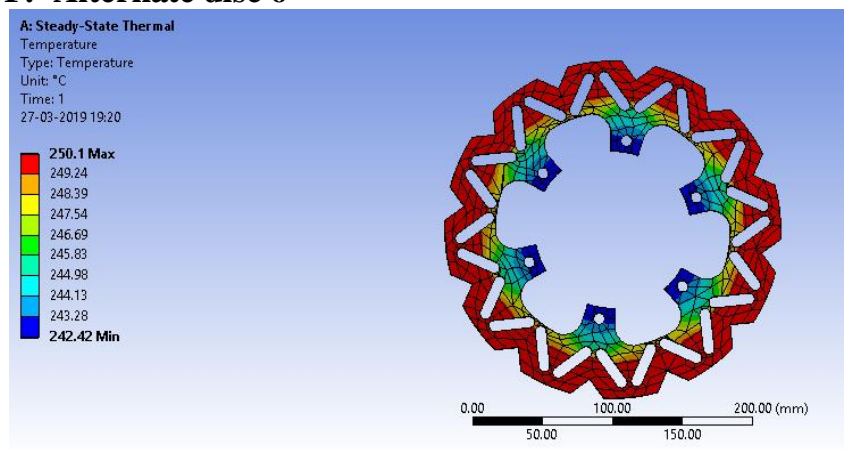

Fig. (f). Temperature of alternate disc

VI. RESULTS 
A. Standard disc 1

\begin{tabular}{ll}
\hline PARAMETERS & VALUES \\
\hline TOTAL DEFORMATION $(\mathrm{mm})$ & 0.0018638 \\
DIRECT DEFORMATION $(\mathrm{mm})$ & 0.0002323 \\
VON - MISSES STRESS $(\mathrm{MPa})$ & 1.085 \\
MAX PRINCIPAL STRESS $(\mathrm{MPa})$ & 0.56155 \\
WEIGHT $(\mathrm{kg})$ & 1.0656 \\
TEMPERATURE $\left({ }^{\circ} \mathrm{C}\right)$ & 249.41 \\
TOTAL HEAT FLUX $\left(\mathrm{W} / \mathrm{mm}^{\wedge} 2\right)$ & 0.0018928 \\
\hline
\end{tabular}

Tab. (a)

B. Alternate disc 2

\begin{tabular}{lc}
\hline PARAMETERS & VALUES \\
\hline TOTAL DEFORMATION $(\mathrm{mm})$ & 0.0018909 \\
DIRECT DEFORMATION $(\mathrm{mm})$ & 0.0000058284 \\
VON - MISSES STRESS $(\mathrm{MPa})$ & 1.2035 \\
MAX PRINCIPAL STRESS $(\mathrm{MPa})$ & 0.63453 \\
WEIGHT $(\mathrm{kg})$ & 1.0439 \\
TEMPERATURE $\left({ }^{\circ} \mathrm{C}\right)$ & 249.38 \\
TOTAL HEAT FLUX $\left(\mathrm{W} / \mathrm{mm}^{\wedge} 2\right)$ & 0.0028535 \\
\hline
\end{tabular}

Tab. (b)

C. Alternate disc 3

\begin{tabular}{lc}
\hline PARAMETERS & VALUES \\
\hline TOTAL DEFORMATION $(\mathrm{mm})$ & 0.0018844 \\
DIRECT DEFORMATION $(\mathrm{mm})$ & 0.00000037549 \\
VON - MISSES STRESS $(\mathrm{MPa})$ & 1.1924 \\
MAX PRINCIPAL STRESS $(\mathrm{MPa})$ & 0.59846 \\
WEIGHT $(\mathrm{kg})$ & 0.98451 \\
TEMPERATURE $\left({ }^{\circ} \mathrm{C}\right)$ & 249.38 \\
TOTAL HEAT FLUX $\left(\mathrm{W} / \mathrm{mm}^{\wedge} 2\right)$ & 0.0028759
\end{tabular}

Tab. (c)

D. Alternate disc 4

\begin{tabular}{lc}
\hline PARAMETERS & VALUES \\
\hline TOTAL DEFORMATION $(\mathrm{mm})$ & 0.002139 \\
DIRECT DEFORMATION $(\mathrm{mm})$ & 0.00000025394 \\
VON - MISSES STRESS $(\mathrm{MPa})$ & 1.1645 \\
MAX PRINCIPAL STRESS $(\mathrm{MPa})$ & 0.60581 \\
WEIGHT $(\mathrm{kg})$ & 1.0004 \\
TEMPERATURE $\left({ }^{\circ} \mathrm{C}\right)$ & 248.95 \\
TOTAL HEAT FLUX $\left(\mathrm{W} / \mathrm{mm}^{\wedge} 2\right)$ & 0.0044506 \\
\hline
\end{tabular}

Tab. (d)

E. Alternate disc 5

\begin{tabular}{lc}
\hline PARAMETERS & VALUES \\
\hline TOTAL DEFORMATION $(\mathrm{mm})$ & 0.0019249 \\
DIRECT DEFORMATION $(\mathrm{mm})$ & 0.00000040734 \\
VON - MISSES STRESS $(\mathrm{MPa})$ & 1.1911 \\
MAX PRINCIPAL STRESS $(\mathrm{MPa})$ & 0.62355 \\
WEIGHT $(\mathrm{kg})$ & 1.0005 \\
TEMPERATURE $\left({ }^{\circ} \mathrm{C}\right)$ & 248.98 \\
TOTAL HEAT FLUX $\left(\mathrm{W} / \mathrm{mm}^{\wedge} 2\right)$ & 0.0037049 \\
\hline
\end{tabular}

Tab. (e)

F. Alternate disc 6

\begin{tabular}{lc}
\hline PARAMETERS & VALUES \\
\hline TOTAL DEFORMATION $(\mathrm{mm})$ & 0.0050694 \\
DIRECT DEFORMATION $(\mathrm{mm})$ & 0.0000006901 \\
VON - MISSES STRESS $(\mathrm{MPa})$ & 2.6767 \\
MAX PRINCIPAL STRESS $(\mathrm{MPa})$ & 1.4283 \\
WEIGHT $(\mathrm{kg})$ & 0.84944 \\
TEMPERATURE $\left({ }^{\circ} \mathrm{C}\right)$ & 248.25 \\
TOTAL HEAT FLUX $\left(\mathrm{W} / \mathrm{mm}^{\wedge} 2\right)$ & 0.005121 \\
\hline
\end{tabular}

Tab. (f)

VII. CONCLUSION

A clear comparison is made between the results from the tables on the basis of each domain, the DISC 2,4,5,6 is found to deform in a comparatively higher value on applying the same load. The DISC 2,4,5,6 takes up a nominally higher Von-misses stress, comparatively nominal rise in temperature, nominal heat flux, with a slight increase in weight. Thus, the DISC 3 is found to deform in a minimum value on applying the same load. The DISC 3 takes up a nominal Von - misses stress, comparatively nominal rise in temperature, nominal heat flux, with a better weight reduction. Thus, the ALTERNATE DISC 3 is proposed to use instead of the STANDARD DISC 1 brake disc rotor, used in BAJAJ PULSAR 150.

\section{REFERENCES}

[1] Prashant C. Jadhav and Sandip. H. Deshmukh. Simulation and Experimental Investigation of Automotive Disc Brakes for 150CC Pulsar Bike, International Journal of Current Engineering and Technology, E-ISSN 2277 4106, P-ISSN 2347 - 5161.

[2] Manjunath T V , Dr Suresh P M. Structural and Thermal Analysis of Rotor Disc of Disc Brake, International Journal of Innovative Research in Science, Engineering and Technology, ISSN ONLINE(2319-8753), PRINT(2347-6710).

[3] Swapnil R. Umale, Dheeraj Varma. Analysis And Optimization of Disc Brake Rotor, International Research Journal of Engineering and Technology, Volume: 03 Issue: $11 \mid$ Nov 2016, e-ISSN: 2395 -0056, p-ISSN: 2395-0072. 


\section{International Journal of Engineering Applied Sciences and Technology, 2020 \\ Vol. 4, Issue 9, ISSN No. 2455-2143, Pages 286-293 \\ Published Online January 2020 in IJEAST (http://www.ijeast.com)}

[4] R.S.Kajabe,R.R.Navthar,S.P.NeharkarDesign \& Implementation of Disc Brake Rotor By using Modified Shapes. International Journal of Innovative Science, Engineering \& Technology, Vol. 2 Issue 3, March 2015, ISSN 2348 - 7968.

[5] Ali Belhocine. Mostefa Bouchetara. Thermomechanical modeling of dry contacts in automotive disc brakell at International Journal of Thermal science 60 (2012) 161 el 70, 2012 Published by Elsevier Masson SAS.

[6] Jiguang Chen, Fei Gao (2014), ThermoMechanical Simulation of Brake Disc Frictional Character by Moment of Inertia, Research Journal of Applied Science Engineering and Technology 7(2), 227-232.

[7] M. Collignon, L.Cristol, P.Dufrenoy, Y.Desplanques, D.Balloy (2013), "Failure of truck brake discs: A coupled numericalexperimental approach to identifying critical thermomechanical loadings, Tribology International 59, $114-120$.

[8] Pier Francesco Gotowicki, Vinzenco Nigrelli, Gabriele Virzi Mariotti, Dr. Cedomir Duboka (2005), Numerical And Experimental Analysis Of A Pegs-Wing Ventilated Disk Brake Rotor, With Pads And Cylinders, 10th EAEC European Automotive Congress.

[9] Adam Adamowicz, Piotr Grzes (2011), Analyzed disc brake temperature distribution during single braking under nonaxissymmetric load, Applied Thermal Engineering 31, 1003 1012.

[10] O.P. Singh et al (2010), Thermal seizures in automotive drum brakes, Engineering Failure Analysis 17, 1155-1172.

[11] S Naveen Kumar et al (2012) Redesign of Disc Brake Assembly with Lighter Material, International Journal of Engineering Research \& Technology (IJERT), ISSN: 2278- 0181, Vol. 1 Issue 7. Daniel Das.A et al (2013), Structural and Thermal Analysis of Disc Brake in Automobiles, International Journal of Latest Trends in Engineering and Technology (IJLTET), ISSN: 2278-621X, Vol. 2 Issue 3.

[12] D. Murali Mohan Rao, Dr. C. Prasad, T. Ramakrishna (2013), Experimental and
Simulated Studies on Temperature Distribution for Various Disc Brakes, International Journal of Research in Mechanical Engineering \& Technology (IJRMET) Vol. 3, Issue 1, ISSN : 2249-5762 (Online) | ISSN : 2249-5770 (Print), Nov - April.

[13] G. Babukanth and M. Vimal Teja "Transient Analysis of Disk Brake By using Ansys Software" International Journal of Mechanical and Industrial Engineering (IJMIE), ISSN No. 2231 -6477, Vol-2, Issue-1, 2012.

[14] Oder, G., Reibenschuh, M., Lerher, T., Sraml, M.; Samec, B.; Potrc, I. "Thermal And Stress Analysis Of Brake Discs In Railway Vehicles" at International Journal of Advanced Engineering 3(2009)1, ISSN 1846-5900.

[15] Daniel Das.A, Christo Reegan Raj.V, Preethy.S, Ramya Bharani.G "Structural and Thermal Analysis of Disc Brake in Automobiles" at International Journal of Latest Trends in Engineering and Technology (IJLTET) ISSN: 2278-621X Vol. 2 Issue 3 May 2013. 